\title{
36. PALYNOLOGICAL STUDIES ON SAMPLES FROM DSDP LEG 42A
}

\author{
Daria Bertolani Marchetti and Carla Accorsi, Instituto ed Orto Botanico, Università di Bologna, \\ 40126 Bologna, Italy
}

\begin{abstract}
This contribution analyzes the results of two palynological studies conducted on samples of Neogene sediments recovered by Leg $42 \mathrm{~A}$. The first was aimed at deducing climatic changes during the Neogene and found evidence of mild warm climates in the upper Tortonian of Site 375 and of cooler climates in the earliest Pliocene of Site 374. The second reports the results of detailed studies on individual sapropel layers recovered at Site 374 and relates the occurrence of such layers in the Pleistocene to phases of climate amelioration.
\end{abstract}

\section{PRE-MESSINIAN POST MESSINIAN SAMPLES-SITES 374 AND 375}

(D. Bertolani Marchetti)

\section{Introduction}

Palynological investigations were carried out on Messinian and pre-Messinian sediments recorded on DSDP Leg 42A (Figure 1). More meaningful results were obtained previously in the continuously cored Site 132 of Leg 13 in the Tyrrhenian Basin (Bertolani Marchetti and Cita, 1975). Unfortunately many samples recovered on Leg $42 \mathrm{~A}$ were sterile and most levels contained insufficient pollen and spores to draw up a pollen spectrum. Consequently, this investigation is preliminary and represents only a minor contribution to our knowledge of the climatic-vegetational features of the Messinian and pre-Messinian environments.

\section{Methods}

The samples were prepared using standard procedures: thus they were treated with hydrofluoric acid at room temperature for 24 to 48 hours, then boiled in $10 \% \mathrm{NaOH}$ for 10 minutes, this being repeated after washing in hot distilled water. Finally the samples were washed with a solution of water and glycerine. The resulting pollen material was stored in water/ glycerine mixture. Analysis was carried out using a light microscope to compare samples with those reported in current literature (see Bibliography), and with acetolyzed recent samples in the collection in the Istituto Botanico of the University of Bologna.

\section{Results.}

A list of samples treated for this study appears as Table 1. Palynological analysis was worthwhile only on those polliniferous samples from Sites 374 and 375 (Table 2). Consequently the results reported here are applicable to the eastern Mediterranean only. Furthermore, of the eight samples analyzed, only three contained sufficient material to allow percentage calcula- tions. For the remaining five only listings of taxa observed were possible, $(+)$ or $(++)$ depending on abundance. Substantially corroded grains, Hystrichosphaeridia and spores of Bryophyta, were not included in the percentage calculations.

Fern remains are considered with the non-arboreous plants (NAP). Pinus pollen (arboreous plants: AP) that were found, were mainly of the species Pinus haploxylon and Pinus diploxylon. Where classification to one of these was impossible, the pollen was assigned to a "Pinus sp. pl." group.

For details of the climatic inferences drawn from the various taxa the reader is referred to Bertolani Marchetti and Cita (1975, p. 286).

\section{Climatic Interpretations}

Samples from Site 374 , Cores 12 and 22 provided no useful indications of climate during the Messinian. The sample from the side wall Core 25 which is assigned to the early Pliocene has a significant pollen content (Plates 1, 2). Species of pine are dominant (about $45 \%$ ) and are associated with other mountain coniferous pollen, Picea, Cedrus, and Podocarpus, etc. Moderately thermophylous elements are scarce. Nonarboreous plant assemblages occur which are characteristic of moderately warm marsh environments, e.g., Brasenia, while the abundance of Chenopotaceae suggests beach environments were a probable source.

The data suggest a lowering of the boundary of the coniferous belt to near sea level in response to a cooling in climate. Marshes, perhaps as swamp land or salt marsh, were present on the coastal plain. The presence of nearby forests is supported by the occurrence of moss spores of Polytrichum type. A marine environment is indicated by a considerable percentage of Hystrichosphaeridae in vegetative form (about 18\%).

Tortonian floras were analyzed at Site 375 (Plate 2). Only the oldest Sample 5-5, 135-137 cm, contained a rich assemblage which includes pollen from mountain conifers together with mediscratic forest elements, fern 


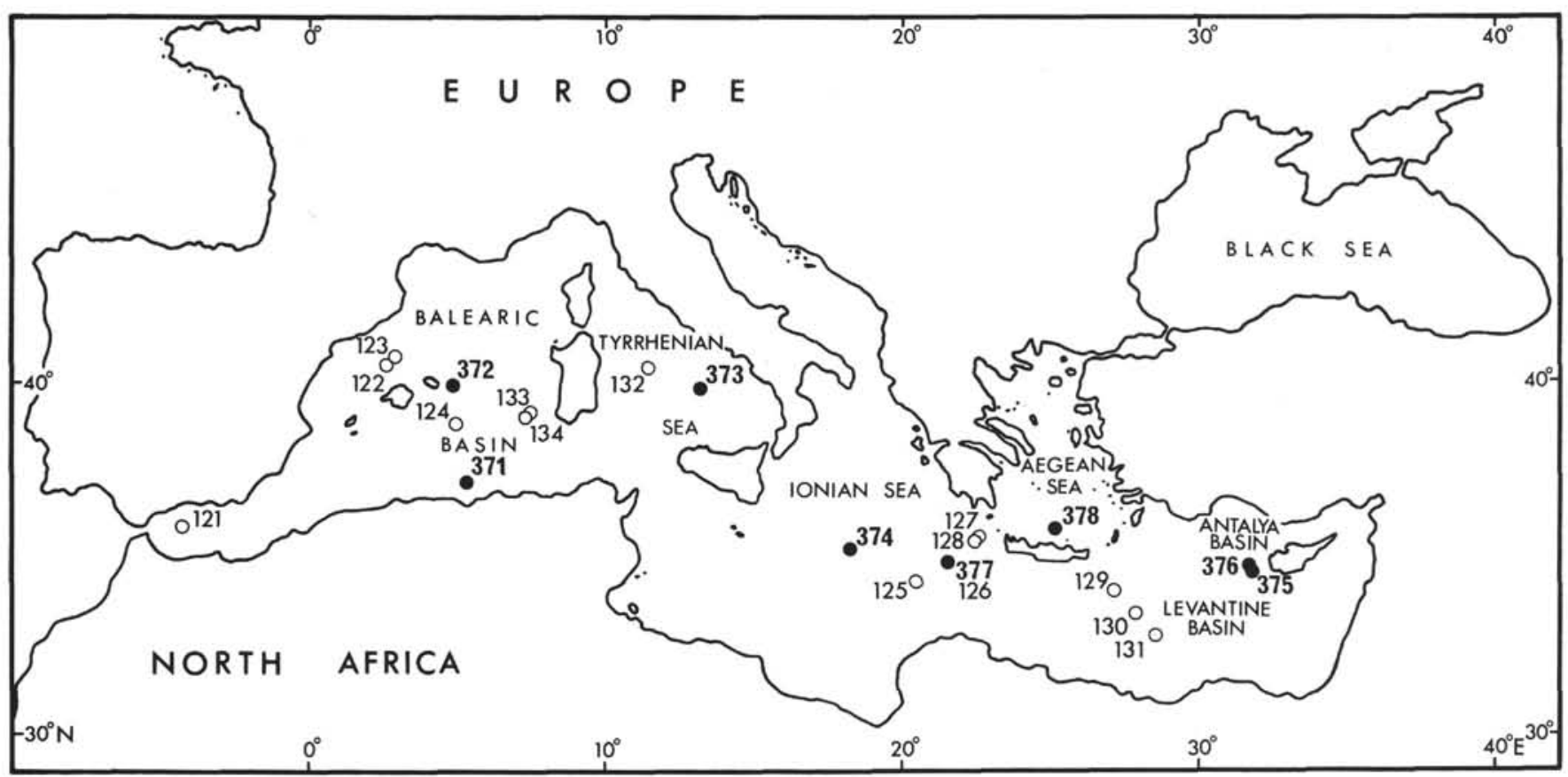

Figure 1. Leg 42A drillsites in the Mediterranean Sea together with those of Leg 13.

TABLE 1

List of Samples Processed

\begin{tabular}{|c|c|c|c|}
\hline $\begin{array}{l}\text { Site and } \\
\text { Location }\end{array}$ & $\begin{array}{c}\text { Sample } \\
\text { (Interval in } \mathrm{cm})\end{array}$ & Age & $\begin{array}{l}\text { Resulting } \\
\text { Material }\end{array}$ \\
\hline \multicolumn{4}{|l|}{371} \\
\hline South Balearic & $8-2,132-135$ & Messinian & Sterile \\
\hline \multirow[t]{3}{*}{ Basin } & $4-2,42-44$ & Upper Pliocene & Sterile \\
\hline & $4-2,83$ & Messinian & Sterile \\
\hline & $5-1,135$ & Messinian & Sterile \\
\hline \multirow{6}{*}{$\begin{array}{l}372 \\
\text { Balearic } \\
\text { Basin }\end{array}$} & $9-1,83-84$ & & \\
\hline & & Serravalian & Sterile \\
\hline & $9-2,0-2$ & or & \\
\hline & $\begin{array}{l}9-2,12-13 \\
9-2,41\end{array}$ & Lower Tortonian & Almost sterile \\
\hline & $9-2,134-135$ & & \\
\hline & $\begin{array}{l}25 \text {-side wall (at } 375 \mathrm{~m} \text { ) } \\
\text { subbottom) }\end{array}$ & Early Pliocene & Polliniferous \\
\hline 374 & $12-1,111-113$ & Messinian & Almost sterile \\
\hline Ionian & $12-2,64-66$ & Messinian & Polliniferous \\
\hline \multirow[t]{4}{*}{ Basin } & $19-1,53-56$ & Messinian & Sterile \\
\hline & $22-1,22$ & Messinian & Polliniferous \\
\hline & $4-3,30-34$ & Upper Tortonian & Polliniferous \\
\hline & $4-4,53-54$ & Upper Tortonian & Scarcely \\
\hline \multirow{3}{*}{$\begin{array}{l}375 \\
\text { Ionian Basin } \\
\text { Florence Rise }\end{array}$} & & & polliniferous \\
\hline & $4-4,55-57$ & Upper Tortonian & Scarcely \\
\hline & $5-5,135-137$ & Upper Tortonian & $\begin{array}{l}\text { polliniferous } \\
\text { Polliniferous }\end{array}$ \\
\hline
\end{tabular}

spores and non-arboreous types such as Chernopodiaceae, Liliiflorae, Graminaceae and Cyperaceae. During this part of the Tortonian a moderately thermophylous forest belt was probably present between a mountain coniferous belt and a coastal plain of open grassland. The climate would have been moderately warm.

The uppermost Tortonian Sample 375-4-3, 30-34 $\mathrm{cm}$, is dominated by coniferous pollen (up to $68 \%$ ) including Pinus and Cedrus. Only a few questionable mediscratic elements are present. Hystrichosphaeridia, often in vegetative form, are abundant, equaling the total pollen and spore count. These confirm that deposition was in a marine environment. The climate of the latest Tortonian is interpreted as having become decidedly cooler, since thermophylous elements are rare or absent.

\section{Conclusions}

The results of these, admittedly few, analyses suggest that the climate of the eastern Mediterranean during the Tortonian was moderately warm and that near the end of that stage it became cooler and thermophylous elements almost entirely disappear. Even cooler climatic conditions are indicated for the earliest Pliocene immediately after the Messinian event. During the Messinian period itself the climate was probably cool oscillations (Marchetti, 1961, 1966, 1972).

\section{PLIOCENE AND PLEISTOCENE SAPROPELITIC SAMPLES, SITE 374 (C. A. ACCORSI)}

\section{Introduction}

The results of an investigation of three horizons from Site 374 are reported here. They include two sapropels: one from Sample 374-5-2, 48-51cm containing $8.99 \%$ organic carbon (Kidd et al., this volume), the other from Sample $374-4$, CC $(2.03 \%$ org. C), which was received along with its associated host marls and was split into four subsamples as in Figure 2 and Table 3. The other sample was of a sapropelic layer containing $1.93 \%$ organic carbon, almost sufficient to also qualify as a sapropel. Ages range from early Pliocene to Pleistocene.

\section{Methods}

For each sample 1 gram of sediment was treated successively with $\mathrm{HCl}(30 \%)$ for 30 minutes, cold $\mathrm{HF}$ (50\%) for 24 hours, and $\mathrm{HCl}(30 \%)$ for 30 minutes, 
TABLE 2

Frequency of Occurrence of Pollen and Spores of Polliniferous Levels in Pre-Messinian and Messinian Samples of Sites 374 and 375

\begin{tabular}{|c|c|c|c|c|c|c|c|c|}
\hline Sample (Interval in $\mathrm{cm}$ ) & $\begin{array}{c}374-22-1, \\
22\end{array}$ & $\begin{array}{c}374-12-2 \\
64-66\end{array}$ & $\begin{array}{c}374-12-1, \\
111-113\end{array}$ & $\begin{array}{c}374-25 \\
\text { (Side Wall) }\end{array}$ & $\begin{array}{l}375-5-5, \\
135-137\end{array}$ & $\begin{array}{c}375-4-4 \\
55-57\end{array}$ & $\begin{array}{c}375-4-4, \\
53-54\end{array}$ & $\begin{array}{c}375-4-3, \\
30-34 \\
\end{array}$ \\
\hline Taxa Age & & Messinian & & Early Pliocene & \multicolumn{4}{|c|}{ Tortonian } \\
\hline AP (Arboreous Plants) & & & & $\%$ & $\%$ & & & \\
\hline Pinus sp. pl. & - & - & - & 24.2 & 23.8 & + & H & 25.0 \\
\hline Pinus haploxylon & + & ++ & - & 12.2 & 19.5 & - & + & 7.1 \\
\hline Pinus diploxylon & - & - & - & 6.2 & - & - & - & 14.3 \\
\hline Abies & - & + & - & 3.0 & - & - & - & - \\
\hline cf. Keteleeria & - & - & - & - & - & - & + & - \\
\hline Picea & - & - & - & 1.5 & - & - & - & - \\
\hline Cedrus & + & - & + & 7.1 & - & - & - & 21.4 \\
\hline Larix & - & - & - & - & 2.2 & - & - & - \\
\hline Podocarpos & - & + & + & 21.4 & - & - & - & - \\
\hline Cryptomeria & - & + & - & - & 2.2 & - & + & - \\
\hline cf. Cephalotaxus & - & - & - & - & - & + & - & - \\
\hline Taxus & - & + & + & - & - & - & - & - \\
\hline Taxodiaceae Seq./Tax. typus & - & - & + & - & 2.2 & - & + & - \\
\hline Alnus & - & - & - & - & - & - & + & - \\
\hline Quercus & - & + & + & - & 2.2 & - & + & - \\
\hline Zelkova & - & - & - & - & 2.2 & - & - & - \\
\hline Eucommia & - & + & - & - & - & - & - & - \\
\hline Carya & - & - & - & - & 2.2 & - & - & - \\
\hline Engelhardtia & - & - & - & - & 4.3 & - & - & - \\
\hline cf. Magnolia & + & - & - & - & 2.2 & - & - & 7.1 \\
\hline Myrica & - & - & - & 1.5 & - & - & - & - \\
\hline Moraceae & - & + & - & - & - & - & - & - \\
\hline Cornus & - & + & - & - & - & - & - & - \\
\hline Rhus & - & + & - & - & - & - & - & - \\
\hline Meliaceae & - & - & - & - & - & - & - & 3.6 \\
\hline Hamamelidaceae & - & - & - & - & 2.2 & - & - & - \\
\hline Ampelidaceae & - & - & + & - & - & - & - & - \\
\hline \multicolumn{9}{|l|}{ NAP (Non-arboreous Plants) } \\
\hline Graminaceae & - & - & - & 3.0 & 2.2 & + & - & 3.6 \\
\hline Cyperaceae & - & - & - & 1.5 & 2.2 & + & - & 3.6 \\
\hline Brasenia & - & - & - & 4.5 & - & - & - & - \\
\hline Chenopodiaceae & ++ & + & - & 6.2 & 2.3 & + & - & - \\
\hline Compositae & - & - & + & 1.5 & - & - & - & 3.6 \\
\hline cf. Thalictrum & - & - & - & - & 6.5 & - & - & - \\
\hline Liliiflorae & - & - & - & - & 2.2 & - & - & - \\
\hline NAP varia & - & - & - & 6.2 & 2.2 & + & + & 10.7 \\
\hline Filicales & - & + & + & - & 8.7 & - & + & - \\
\hline Lycopodium & - & + & - & - & - & - & - & - \\
\hline Bryophyta & - & - & - & 3.0 & 4.3 & - & - & - \\
\hline Hystrichosphaeridia & - & + & - & 18.4 & 4.3 & - & - & 99.9 \\
\hline Corroded grains & - & + & ++ & - & - & - & - & 7.1 \\
\hline Mediocratic taxa & - & + & + & 6.0 & 15.3 & - & + & 10.7 \\
\hline AP/NAP (approximate ratio) & - & - & - & $77 / 23$ & $72 / 28$ & - & - & $79 / 21$ \\
\hline
\end{tabular}

each stage interspersed with washing. These were followed by two 7-minute periods of boiling in $\mathrm{NaOH}$ ( $10 \%)$ and then by immersion in $\mathrm{HNO}_{3}(65 \%)$ for 3 minutes. If the sample was from the sapropel or sapropelic layer itself, additional treatment using an Erdtman's acetolysis was employed. The last stages of preparation for each sample were washings successively in distilled water, boiling water, and a solution of glycerine and distilled water. The resulting material was introduced into a solution of distilled water and glycerine and made up to a 5 -cc volume.

For the calculation of absolute pollen frequency (APF), which expresses the number of pollen plus Pteridophyta spores in 1 gram of sediment, a modifica- tion of the method of Accorsi and Rodolfi (1975) was employed. This involved pipeting off a $0.02-\mathrm{cc}$ drop from each 5-cc volume solution of distilled water and glycerine mixed with the treated sample material. The number of grains detected in each whole drop permitted the calculation of APF using the formula:

$$
\mathrm{APF}=\frac{\mathrm{ng} \cdot \mathrm{Vp}}{\mathrm{Wp} \cdot \mathrm{Vd}}
$$

where ng =total number of grains in the drop;

$$
\begin{aligned}
& \mathrm{Vp}=\text { preparation volume; } \\
& \mathrm{WP}=\text { preparation initial weight; } \\
& \mathrm{Vd}=\text { volume of drop. }
\end{aligned}
$$




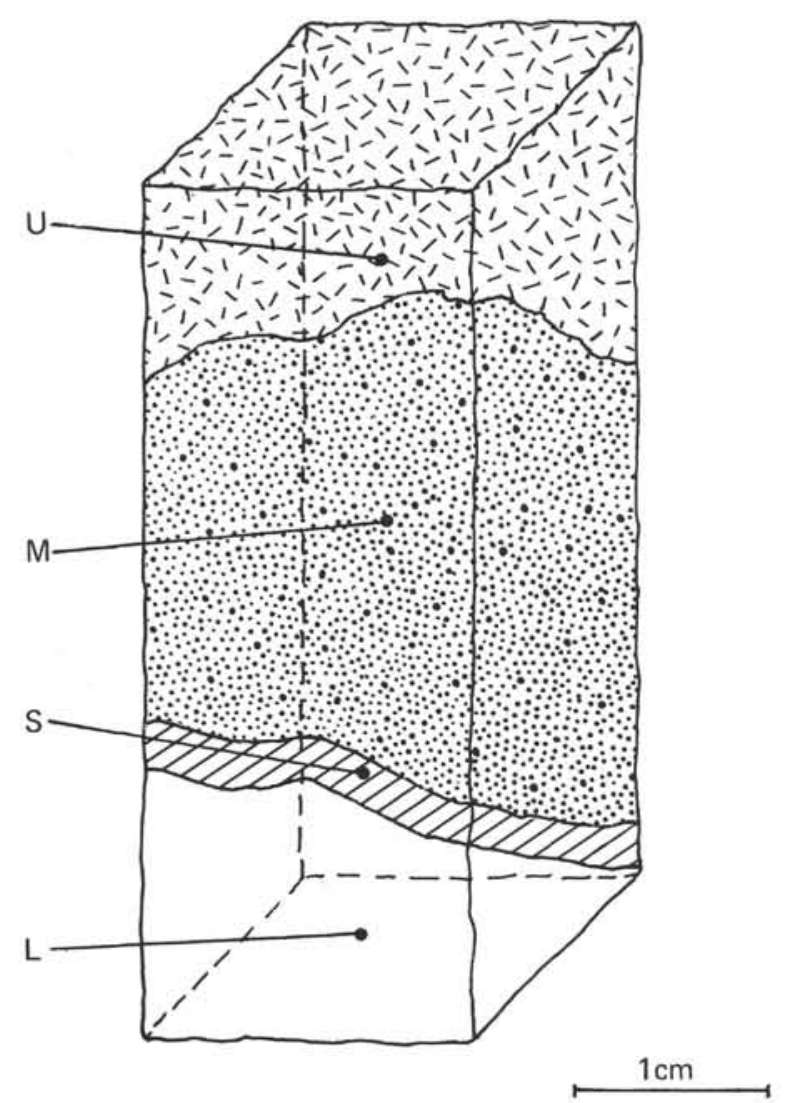

Figure 2. Levels sampled in Sample 374-4, CC. $(L=$ olive-gray marl; $S=$ whitish marl; $M=$ dark brown sapropel; $U=$ olive-gray marl).

TABLE 3

Samples of Pliocene and Pleistocene Sapropelitic Sediments and Associated Marls Investigated From Site 374

\begin{tabular}{|c|c|c|c|c|}
\hline Core & Section & $\begin{array}{c}\text { Meters } \\
\text { Subbottom }\end{array}$ & Lithology & Age \\
\hline 4 & CC (Level Upper) & $T$ & Olive-gray marl & \\
\hline 4 & CC (Level Middle) & & Dark brown sapropel & \\
\hline 4 & CC (Level Sterile) & 150 & Whitish marl & Pleistocene \\
\hline 4 & CC (Level Lower) & 1 & Olive-gray marl & \\
\hline 5 & $2,48-51 \mathrm{~cm}$ & $\overline{\sim 300}$ & Black sapropel layer & Late Pliocene \\
\hline 9 & $2,0-7 \mathrm{~cm}$ & $\sim 360$ & Black sapropelic layer & Early Pliocene \\
\hline
\end{tabular}

Results

All samples were polliniferous (Table 3) except the whitish marl, Level S, of Sample 4, CC (Figure 2). The five other samples were sufficiently rich in pollen and spore material (total grain counts range from 351 to 2093 ) to allow the calculation of percentage frequencies as in Table 4.

An examination of the taxa recorded during the light microscopic analysis allows the identification of a number of groups which have environmental significance:

1) Conifers and other associated types typical of a mountain forest belt: Pinus, Abies, Truga, Cedrus, etc. Additionally some species of Pinus may have been derived from lowerlying vegetational belts (e.g., Pinus type halepensis and Pinus type brutia).
2) More or less thermophylous hardwoods such as Quercus, Ulmus, Zelkova, Carya, and Pterocarya.

3) Typical elements of steppe (Artemisia) and Mediterranean macchia or gariga environments such as the arboreous plants (AP) Pistacia, Phyllirea, and Buxus and the non-arboreous plants (NAP) Umbelliferae and Labiatae. Also within this group is the xerophytic taxon Ephedra.

4) Characteristic elements of salt grassland vegetation, from areas at times flooded by the sea, such as Chenopodiaceae, Graminaceae, Compositae pro parte, and Statice.

5) Hydrophytes: including a group of plants that grow in slow running or almost stagnant water, such as Potamogeton, Hydrocharis, Ceratophyllum, Alisma pro parte, Sagittaria, Lemna, Nymphaea, and Nuphar, together with a group that is characteristic of the shores of fresh water lakes or riverbanks, such as Lythrum, Alisma, Typha, Graminaceae, and Cyperaceae pro parte. A tropical association including Nymphaea and Brasenia is also characteristic of this latter environment.

\section{Climatic and Environmental Interpretation}

Sample 9-2, 0-7 cm-Early Pliocene: In this sample non-arboreous material is dominant $(\mathrm{AP} / \mathrm{NAP}=34$ / 66) (Plates 3 to 7). Conifers are abundant; for example, Pinus makes up about $20 \%$ of the total, much of which is Pinus haploxylon. The other conifers are recorded in low percentages, but nevertheless show a much greater variation in tertiary entities (see Sequoia, Sciadopitys, Podocarpus dacrydiodes, Tsuga, Cedrus, etc.) than in the other samples examined. Hardwood types are represented by Quercus (about $2 \%$ ), together with the thermophylous Zelkova, Carya, Platycarya, and Ulmus. Elements of a tertiary thermophylic bushy vegetation are represented by Palmae, Buxus, Laurus, Ampelidaceae, Myrica, and Pistacia. The Hydrophyte group is well represented in this sample indicating fresh and slow running or almost stagnant water conditions. A further feature of this sapropelic layer is the presence of fungal spores in much higher percentages than in the other samples examined.

The dominance of the NAP can be explained by derivation from a far forest source and from a belt of herbaceous dry vegetation in the neighborhood. The conifer elements may have come from a higher forest belt. The remarkable amount of Hydrophyte elements, along with the associated Chenopodiaceae, suggest a coastal salt lake environment, although a delta region remains a possibility. The climate which would be associated with this vegetational picture is interpreted as temperate, cool, and damp.

Sample 5-48-51 cm-Late Pliocene: In comparison with the assemblage described above, this sample has a lower amount of arboreous plant derivatives and Pinus makes up about half of these (Plates 5 to 7). The Pinus haploxylon percentage is considerably diminished and several mountain elements disappear. Thermophylous wood derivatives are more prominent and the steppe and xerophytic elements are well repre- 
TABLE 4

Frequency of Occurrence of Pollens and Spores Recorded in Pliocene and Pleistocene Samples of Site 374

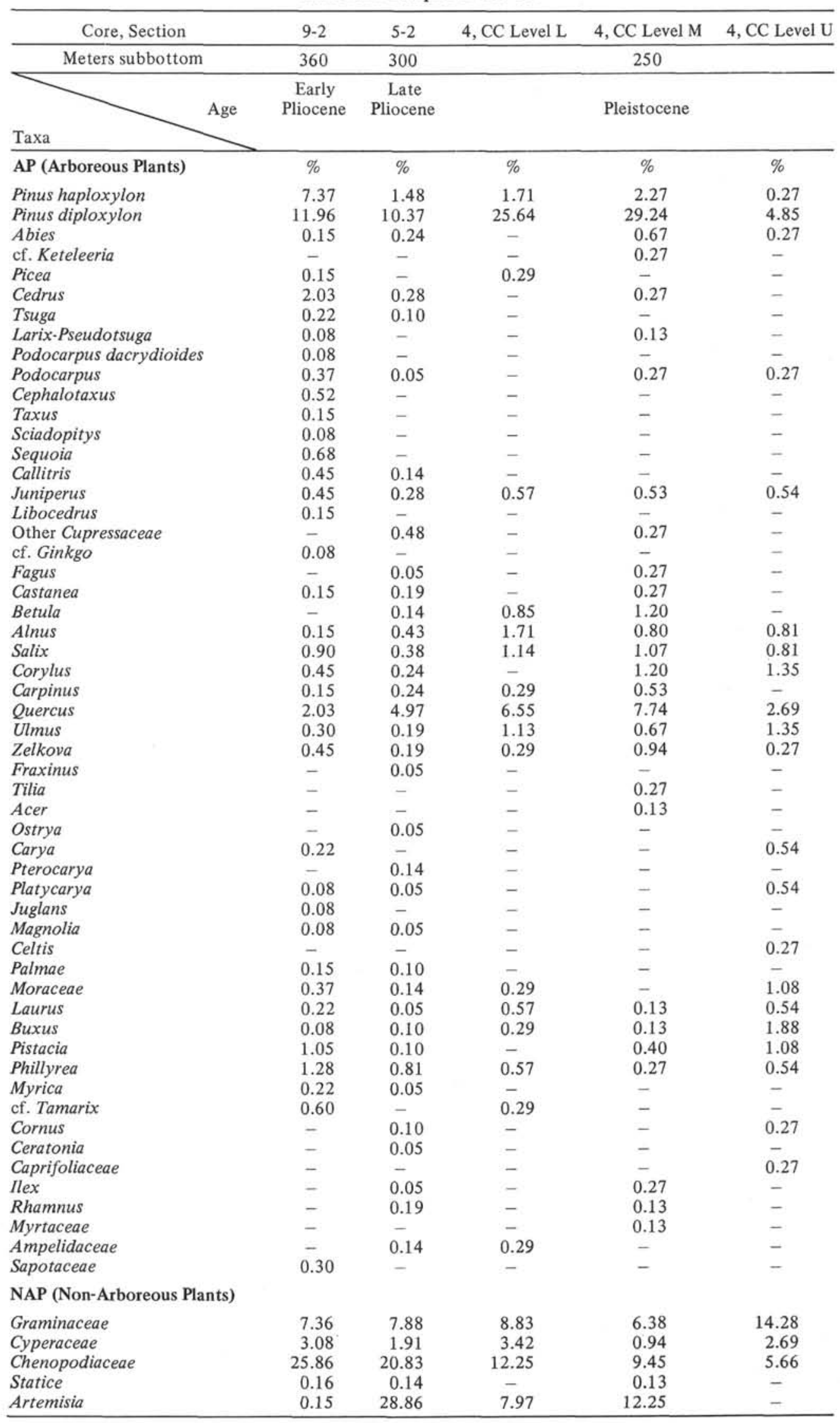


TABLE 4 - Continued

\begin{tabular}{|c|c|c|c|c|c|}
\hline Core Section & $9-2$ & $5-2$ & 4, CC Level L & 4, CC Level M & 4, CC Level U \\
\hline Meters subbottom & 360 & 300 & & 250 & \\
\hline Age & $\begin{array}{c}\text { Early } \\
\text { Pliocene }\end{array}$ & $\begin{array}{c}\text { Late } \\
\text { Pliocene }\end{array}$ & & Pleistocene & \\
\hline \multicolumn{6}{|l|}{ Taxa } \\
\hline Ericales & 0.08 & 0.14 & 1.99 & 0.40 & 0.27 \\
\hline Ephedra & 2.63 & 4.44 & 5.12 & 4.54 & 1.35 \\
\hline Gnetum & 0.15 & - & - & - & - \\
\hline Compositae (Tubuliflorae type) & 1.50 & 2.00 & 1.99 & 2.54 & 1.62 \\
\hline Compositae (Liguliflorae type) & 0.53 & 0.67 & 0.85 & 0.53 & 1.08 \\
\hline Plantago & 2.18 & 0.72 & 0.57 & 1.07 & 0.27 \\
\hline Umbelliferae & 0.45 & 1.15 & 0.57 & 0.27 & - \\
\hline Liliiflorae & 0.97 & 0.10 & 0.85 & 1.07 & 39.88 \\
\hline Amaryllidaceae & - & 0.05 & - & - & - \\
\hline Potamogeton & 9.25 & - & 0.29 & 0.13 & 0.27 \\
\hline Juncaceae & 2.25 & - & - & - & - \\
\hline Alisma & 1.88 & 0.67 & - & - & 0.27 \\
\hline Lemna & 0.45 & 0.14 & 0.29 & - & 0.81 \\
\hline Nymphaea & 0.08 & - & - & - & - \\
\hline Nuphar & 0.08 & - & - & - & - \\
\hline Ceratophyllum & 0.15 & - & - & - & - \\
\hline Sagittaria & 0.15 & - & - & - & - \\
\hline Hydrocharis & 0.08 & - & - & - & - \\
\hline Brasenia & 0.75 & - & - & - & - \\
\hline Lythrum & - & 0.91 & - & - & - \\
\hline Typha & 0.97 & 0.10 & 0.29 & - & 0.27 \\
\hline Stratiotes & 0.08 & - & - & - & - \\
\hline Araceae & 0.15 & - & - & - & - \\
\hline Thalictrum & 0.53 & 1.91 & - & 0.94 & - \\
\hline Other Ranuncolaceae & 0.53 & 0.57 & 2.28 & 1.20 & 0.27 \\
\hline Rosaceae & 0.08 & 0.33 & 2.28 & 1.21 & 0.81 \\
\hline Labiatae & 0.15 & 0.19 & 1.14 & 0.27 & - \\
\hline Scrophulariaceae & - & - & 1.14 & - & - \\
\hline Cistaceae & - & - & - & 0.27 & - \\
\hline Geraniaceae & - & - & - & 0.27 & 0.27 \\
\hline Leguminosae & 0.08 & 0.38 & 1.71 & 0.80 & 0.27 \\
\hline Caryophyllaceae & 0.08 & 0.33 & - & 0.27 & - \\
\hline Rubiaceae & 0.37 & 0.20 & - & 0.13 & 1.62 \\
\hline Thymeleaceae & - & - & - & 0.13 & 0.54 \\
\hline Urticaceae & 0.22 & - & - & - & 0.27 \\
\hline Campanula & 0.08 & 0.19 & - & 0.13 & 0.27 \\
\hline Polygonum & - & 0.05 & - & - & - \\
\hline Amaranthaceae & 0.08 & - & - & - & - \\
\hline Saxifragaceae & 0.30 & 0.38 & - & - & - \\
\hline Hypericum & - & 0.19 & - & 0.13 & - \\
\hline Rumex & - & 0.03 & - & 0.13 & - \\
\hline Euphorbiaceae & 0.15 & - & - & - & - \\
\hline NAP varia & 0.46 & 1.20 & 1.71 & 2.08 & 3.23 \\
\hline Filicales & 0.83 & 0.38 & 1.99 & 1.87 & 2.97 \\
\hline Equisetales & 0.37 & - & - & - & - \\
\hline Lycopodium & - & - & - & - & 0.27 \\
\hline Fungal spores & 510 & 84 & 32 & 82 & 45 \\
\hline Hystrichosphaeridia & 4.5 & 3.9 & 2.4 & 4.7 & 2.9 \\
\hline Mediocratic taxa & 8.34 & 8.24 & 10.56 & 13.21 & 12.67 \\
\hline Mediocratic taxa (\% on AP) & 24.33 & 36.36 & 24.86 & 26.17 & 61.84 \\
\hline AP/NAP (approximated ratio) & $34 / 66$ & $23 / 77$ & $43 / 57$ & $51 / 49$ & $21 / 79$ \\
\hline \multicolumn{6}{|l|}{ Total Pollen and Pteridophyta } \\
\hline spores & 1330 & 2093 & 351 & 749 & 371 \\
\hline APF & 22750 & 35500 & 1500 & 14750 & 1750 \\
\hline
\end{tabular}

sented. Elements of fresh water environments are almost absent and those of the herbaceous xerophylous belt considerably increase (Artemisia and Chenopodiaceae).

The late Pliocene environments suggested by this assemblage indicate a marine coast with a climate comparatively warmer and drier than that of the early
Pliocene. This change may be related to a eustatic rise in sea level which broke into the early Pliocene coastal basins.

Sample 4, CC-Pleistocene: In the lowest subsample (Level L) the APF was calculated at 1500, the lowest pollen abundance recorded for any of the samples, which is probably related to its marl composition. 
Percentages of arboreous plant derivatives, represented mainly by conifers, are considerably lower than those of herbaceous types. The only tertiary elements are Pinus haploxylon and Zelkova (Plate 7).

As noted previously the whitish marl of Level S between Levels $\mathrm{L}$ and $\mathrm{M}$ was entirely devoid of pollen.

The central part of this sapropel horizon, Level M, contained a fairly rich assemblage $(\mathrm{APF}=14,750)$ but one which was poorly conserved and showed frequent conclusions (Plate 7). In comparison with Level L, the arboreous elements show a slight increase $(\mathrm{AP} / \mathrm{NAP}=$ 51/49) mostly in the form of Pinus in relatively high percentages. Thermophylous derivatives are in the minority, but they make up a greater proportion of the AP total and are more varied.

The marl of the uppermost subsample, Level U, has an expectedly low pollen frequency $(\mathrm{APF}=1750)$ (Plate 5), and the arboreous vegetation is again dominated by the non-arboreous, with the AP/NAP reverting to $21 / 79$. The arboreous elements are mostly thermophylous types including Zelkova, together with Carya and Pterocarya which were not present in the underlying levels. The total assemblage is entirely dominated by herbaceous elements such as Graminaceae, Chenopodiaceae, Cyperaceae, Liliiflorae.

The results of analyzing the subsamples of this core catcher allow an interpretation of changing environments within a narrow period of sediment deposition. The assemblages show an upward warming in climate which is interpreted as a regression phase of a cold oscillation. According to this interpretation, the derivatives of a coniferous belt, indicative of cold conditions, almost dominate in the lower and middle levels. In Level $M$, we can identify the development of thermophylous forest with a rich undercover. This hardwood vegetation is replaced by a herbaceous cover in the upper level which would be developed in a warm dry climate.

\section{Conclusions}

Only the core catcher group of subsamples can give an insight to continuous environmental changes during the deposition of an individual sapropel horizon. This shows that the sapropel in question was deposited during a warming in climate. The other samples allow some comparison with conditions during deposition of similar sediments in the Pliocene. On the other hand, the small number of samples studied do not permit discussion of the causes of basinwide stagnation.

The early Pliocene assemblage characterizes a damp, cool, temperate climate. This can be compared with the results of the analysis of a sample from the lowermost Pliocene (374-side wall Core 25), as described in the first part of this contribution. This exercise shows a climatic change from cold to somewhat warmer conditions in the sapropelic layer. In all three Pliocene samples examined the floras are impoverished and many tertiary elements are absent.

The early Pleistocene group of subsamples from Sample 374-4, CC, are interpreted as the result of a warming trend following a cold oscillation in climate.
It is possible that this may also have been the case for the Pliocene sapropel and sapropelic layers investigated and that we should confirm whether cold (glacial?) climates may have extended into pre-Quaternary time.

\section{REFERENCES}

Accorsi, C. A. and Rodolfi, G., 1975. Primi risultati sullo studio di un suolo calcimorfo delle Alpi Apuane in relaxione ad analisi palinologiche e microbiologiche: Boll. Soc. Ital. Scienze Suolo, v. 9, p. 35-51.

Bertolani Marchetti, D. 1961. Vicende di una antichissima laguna veneta messe in luce da ricerche palinologiche: Mem. Biogeogr. Adr., v. 5, p. 9.

1966. Prime ricerche paleobotaniche sulla formazione messiniana gessosa del Bolognese. Atti Soc. Nat. e Mat. Modena 93, p. 4.

1972a. Dati paleobotanici. In La grotta Michele Gortani 31E BO a Gessi di Zola Predosa (Bologna). Rass. Speleol. Ital. Mem. 10, Atti VII Conv. Speleol. EmiliaRomagna e Simposio Studi sulla Grotta del Farneto, p. 235-237.

1972b. Flora pollinica terziaria negli interstrati marnosi della formazione gessosa bolognese: ibid., p. 186189.

Bertolani Marchetti, D. and Cita, M. B., 1975. Studi sul Pliocene e sugli strati di passaggio dal Miocene al Pliocene. VII) Palynological Investigations on Late Messinian sediments recorded at DSDP Site 132 (Tyrrhenian Basin) and their bearing on the deep basin desiccation model: Riv. Ital. Paleont., v. 81, p. 281-308.

\section{ADDITIONAL SELECTED REFERENCES}

Benda, L., 1973. Late Miocene sporomorph assemblages from the Mediterranean and their possible paleoclimatological implication. In Drooger, C. (Ed.), Messinian events in the Mediterranean, Amsterdam (Kon. Ned. Akad. Wetensch., p. 256-259.

Benda, L. and Meulenkampf, J. E., 1972. Discussion on biostratigraphic correlations in the Eastern Mediterranean Neogene: Zeit. Deutsch. Geol. Ges., v. 123, p. 559-564. 1975. Preliminary palynological data on proposed Plio-Pleistocene boundary type-section of Le Castella: Ateneo Parmense-Acta Naturalia, v. 11, p. 467-485.

Bertolani Marchetti, D. and Del Chicca, M. G., 1966. Palynological researches about sediments in Messinian "Formazione gessoso-solfifera", in Emilia and Sicily: Giorn. Bot. Ital., v. 73, p. 235-237 Firenze.

Erdtman, G., 1943. An introduction to pollen analysis: Chronica Botanica, v. 12, p. 1-239.

, 1952. Pollen and spore morphology and plant taxonomy: (I) Angiospermae.

, 1967. ibid (II) Gymnospermae, Pteridophyta, Bryophyta.

Erdtman, G., Berglund, B. and Praglowski, J., 1961 and 1963. An introduction to a Scandinavian pollen flora: v. 1 and 2 .

Evitt, W. R., 1969. Dinoflagellates and other organisms in paleogeological preparations. In Tschudi, R. H. and Scott, R. A. (Eds.), Aspects of palynology: p. 377-438.

Horvat, I., Glavac, V. and Ellemberg, H., 1974. Vegetation Südosteuropas, p. 1-768.

Lona, F. and Ricciardi, E., 1961. Studio pollinologico stratigrafico su una serie lacustre pleistocenica dell 'Italia Centrale (Bacino di Gubbio, Perugia): Pollen and Spores, v. 1, p. 93. 
Lona, F. and Bertoldi, R., 1972. La stor a del Plio-Pleistocene italiano in alcune sequenza vegetazionali lacustri e marine: Atti Acc. Naz Lincei, v. 11, p. 1-41.

Pokrowskaia, J. M., 1958. Analyse Pollinique: Serv. Inform. Geol. B. R. G. M., v. 24, p. 1-314.

Ricciardi, E., 1961. Analisi pollinologica dei sedimenti lacustri lignitiferi di Pietrafitta (Perugia, Italia): Pollen and Spores, v. 3, p. 325.

Rossignol, M., 1961. Analyse pollinique de sédiments marins quaternaires en Israel - 1) Sédiments récents: Pollen and Spores, v. 3, p. 303.

Rossignol-Strick, M., 1973. Pollen analysis of some sapropel layers from the Deep Sea Floor of the Eastern Mediterranean. In Ryan, W. B. F., Hsü, K. J., et al., Initial Reports of The Deep Sea Drilling Project, Volume 13: Washington (U.S. Government Printing Office), p. 971-991.

Rudolph, K., 1935. Mikrofloristische Utersuchungen Tertiaeren Ablagerungen in nürdlichen Bühmen: Berd. Bot. Zentralbi., v. 54 , p. $224-238$.

Trevisan, L., 1967. Pollini fossili del Miocene superiore nei Tripoli del Gabbro (Toscana): Palaeontographia Italica, v. 62 , p. $1-75$.

Van der Hammen, T., Wisjmstra, T. A. and Zagwjin, H., 1971. The floral record of the Late Cenozoic of Europe: Late Cenozoic Glacial Ages, p. 391-424.

Zagwjin, W. H., 1967. Ecologic interpretation of a pollen diagram from Neogene beds in the Netherlands: Rev. Paleobot. Palynol., v. 2, p. 173-181. 
PLATE 1
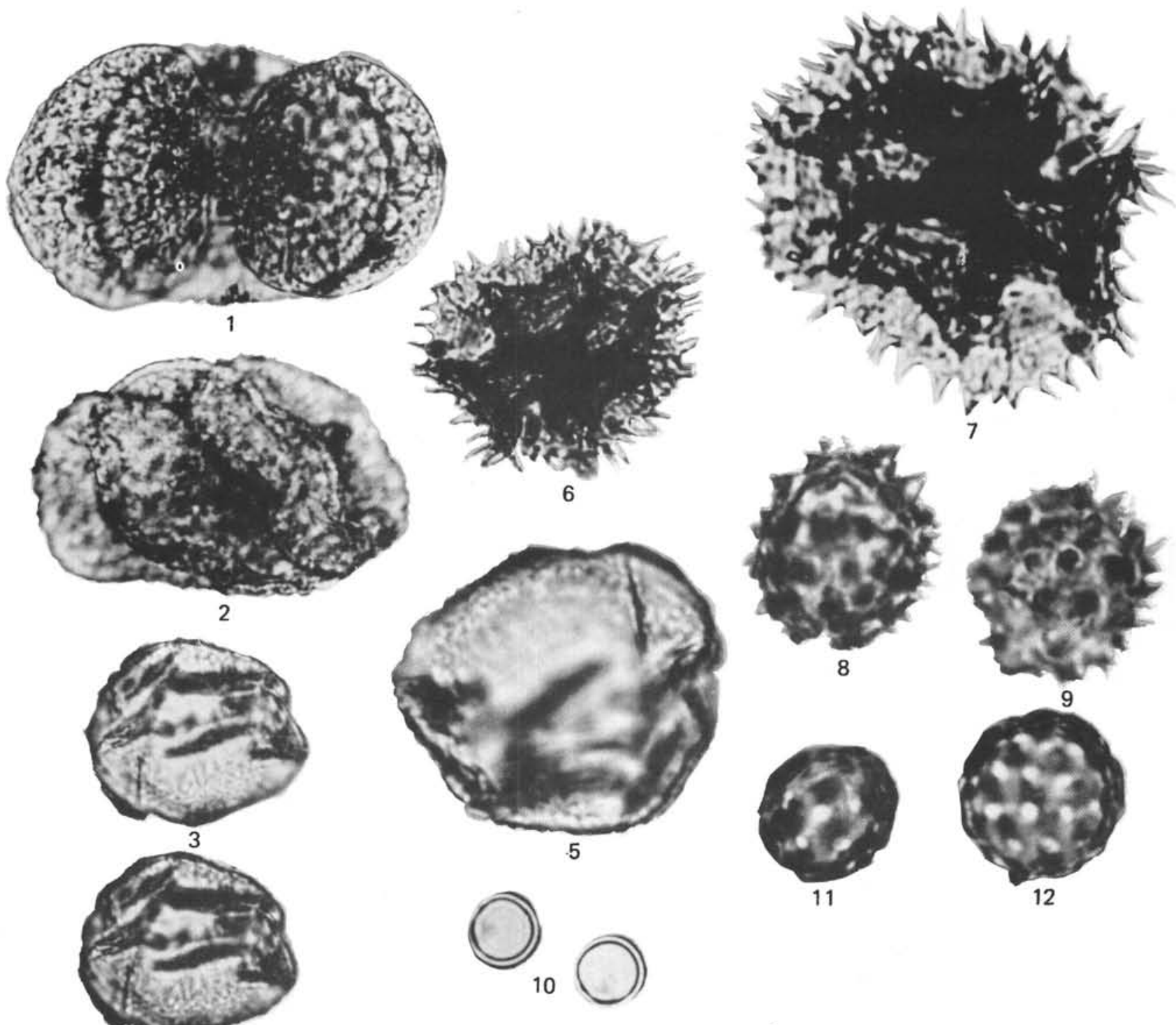

A $\overline{10 \mu \mathrm{m}}$

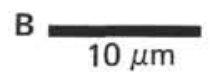

Figures 1, 2, 3, 4, and 6 - Scale A. Figures 5, 7, 8, 9, 10, 11, and 12 - Scale B. All the grains figured in this plate were obtained from Site 374, Side Wall Sample 25.

Figure 1

Figure 2

Figure 3

Figure 4

Figure 5

Figure 6

Figure 7

Figure 8

Figure 9

Figure 10

Figure 11
Pinus.

Pinus.

Brasenia.

The same grain using a different focus.

The same grain at higher magnification.

Compositae (Liguliflorae-type).

The same grain at higher magnification.

Compositae (Tubuliflorae-type).

The same grain using a different focus.

Polytrichum spores (Bryophyta).

Chenopodiaceae. 

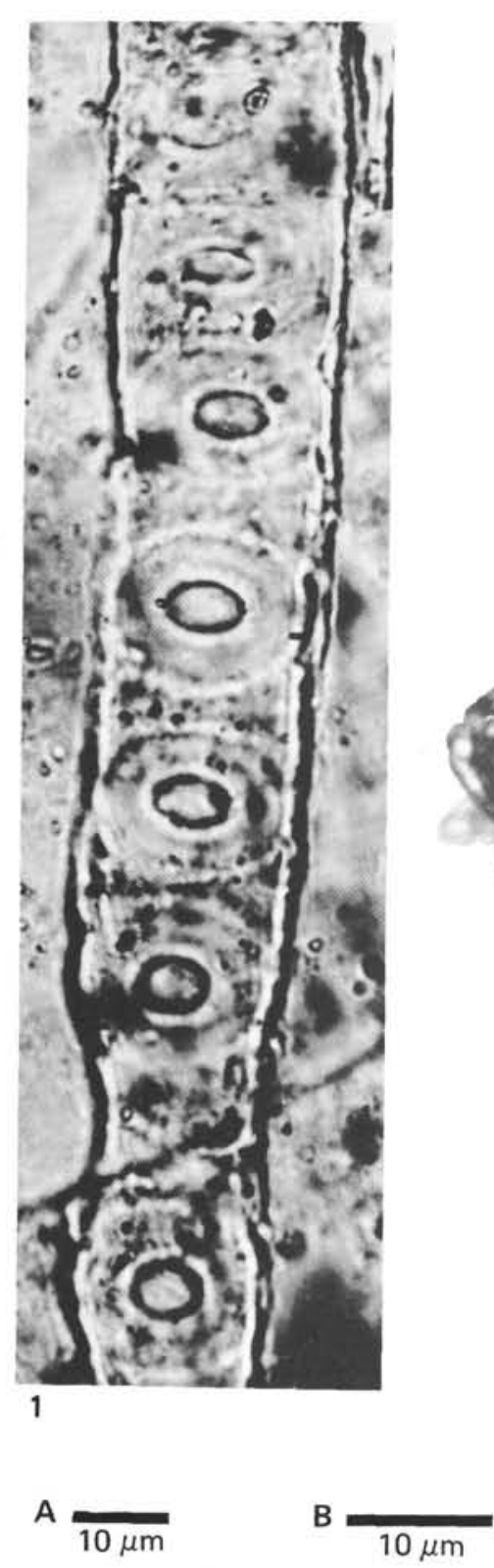
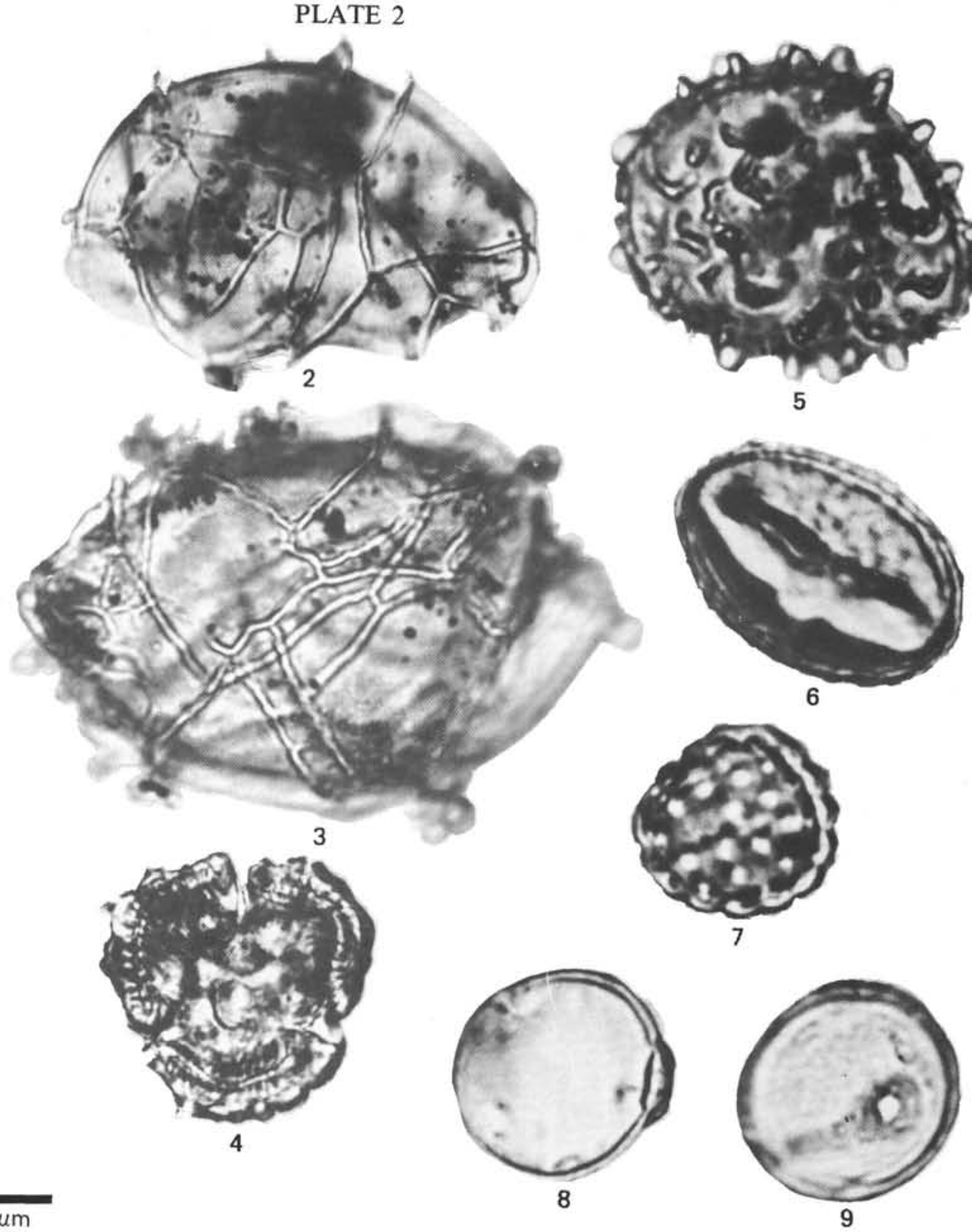
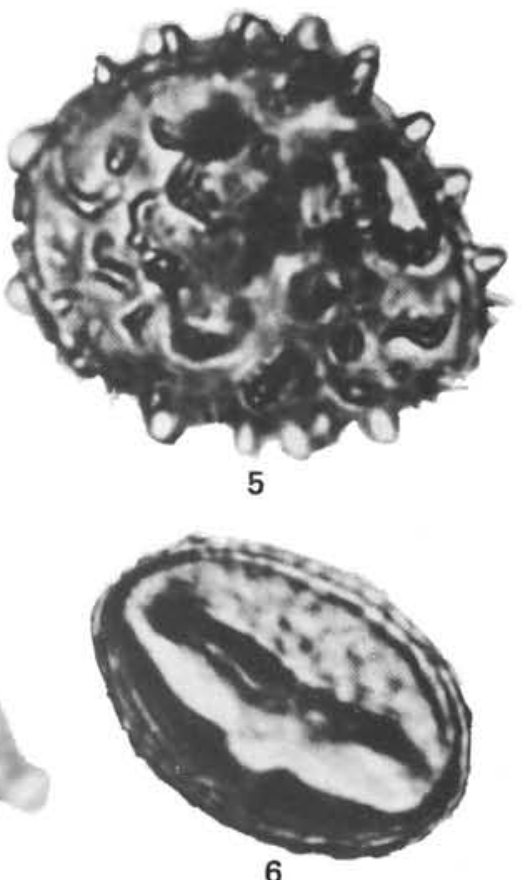

Figures 1, 2, 3, and 4-Scale A. Figures 5, 6, 7, 8, and 9-Scale B. Figure 1

Figure 2

Figure 3

Figure 4
Tracheid in radial section; bordered pits of "modern" type (Abies?). Sample 374-12-1, 111-113 cm.

Hystrichosphaeridia. 374, Side Wall Sample 25.

Hystrichosphaeridia. 374, Side Wall Sample 25.

Compositae (Liguliflorae-type). Sample $375-4-3,30-34 \mathrm{~cm}$.
Figure 5

Figure 6

Figure 7

Figure 8

Figure 9 
PLATE 3

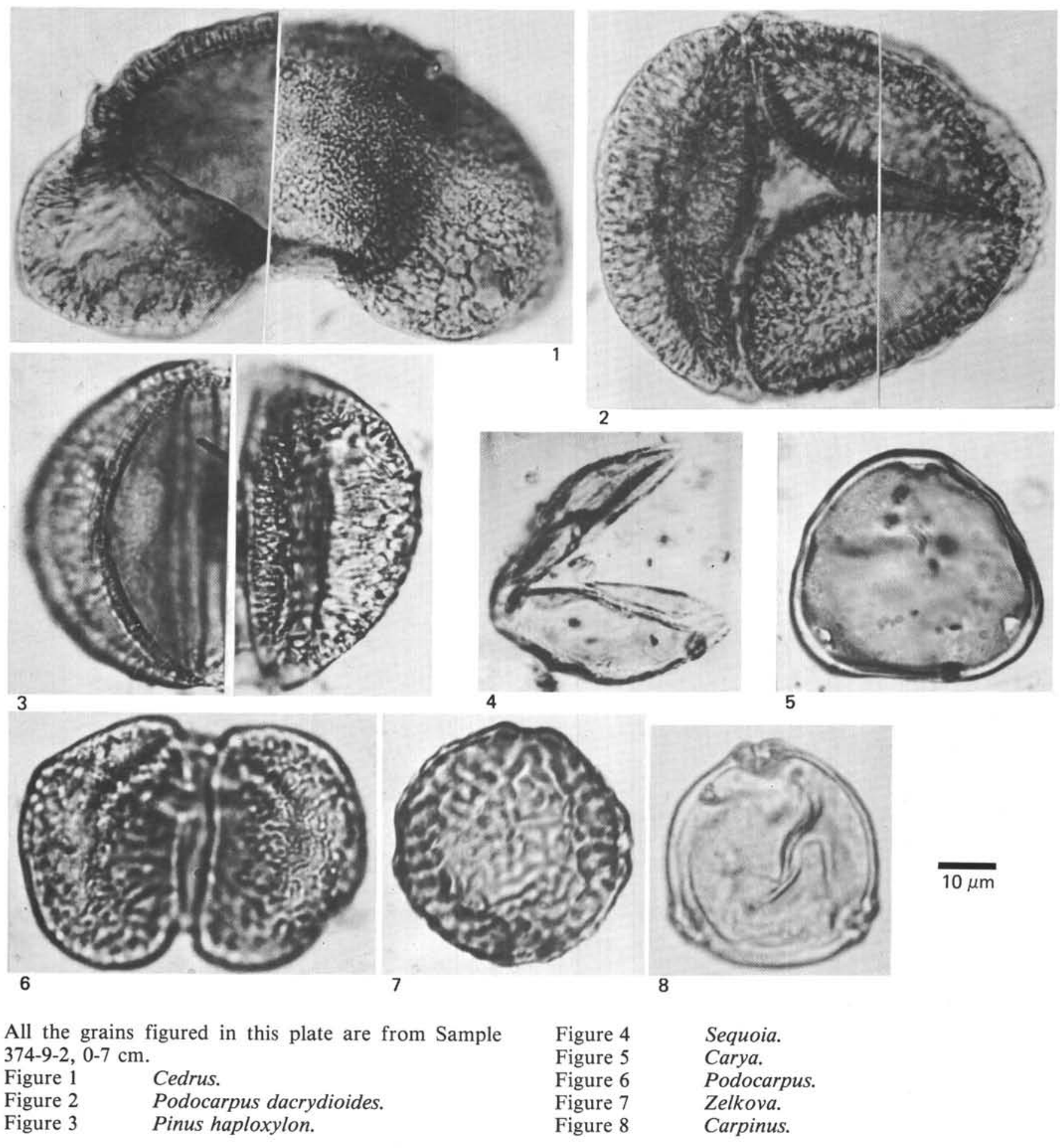


PLATE 4
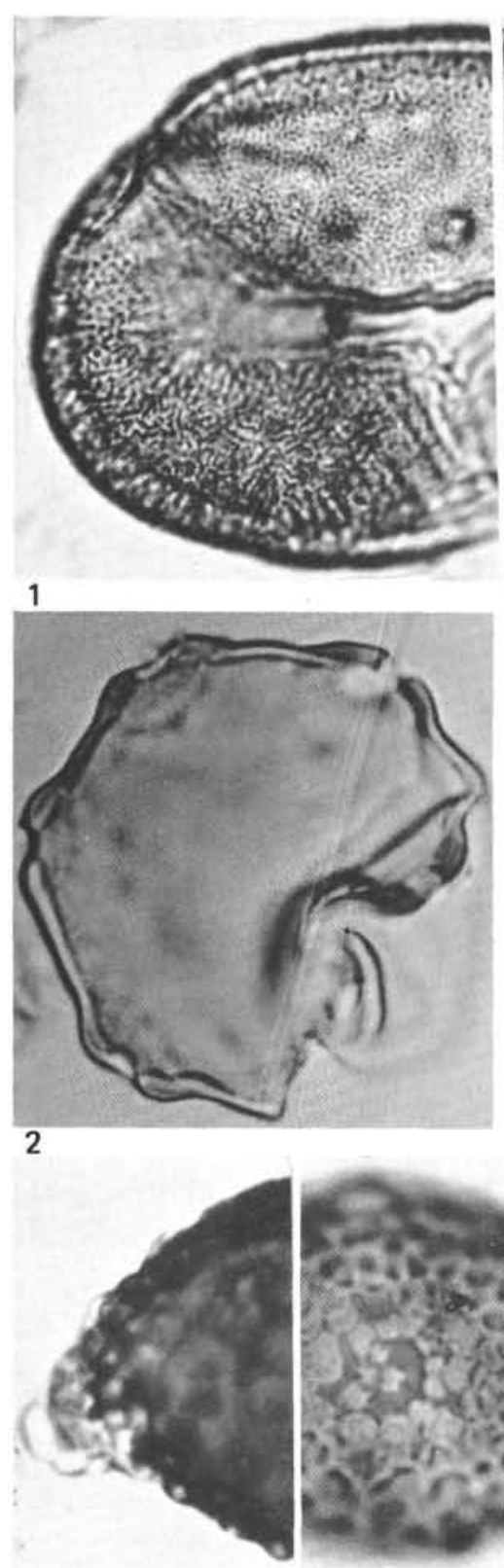

4
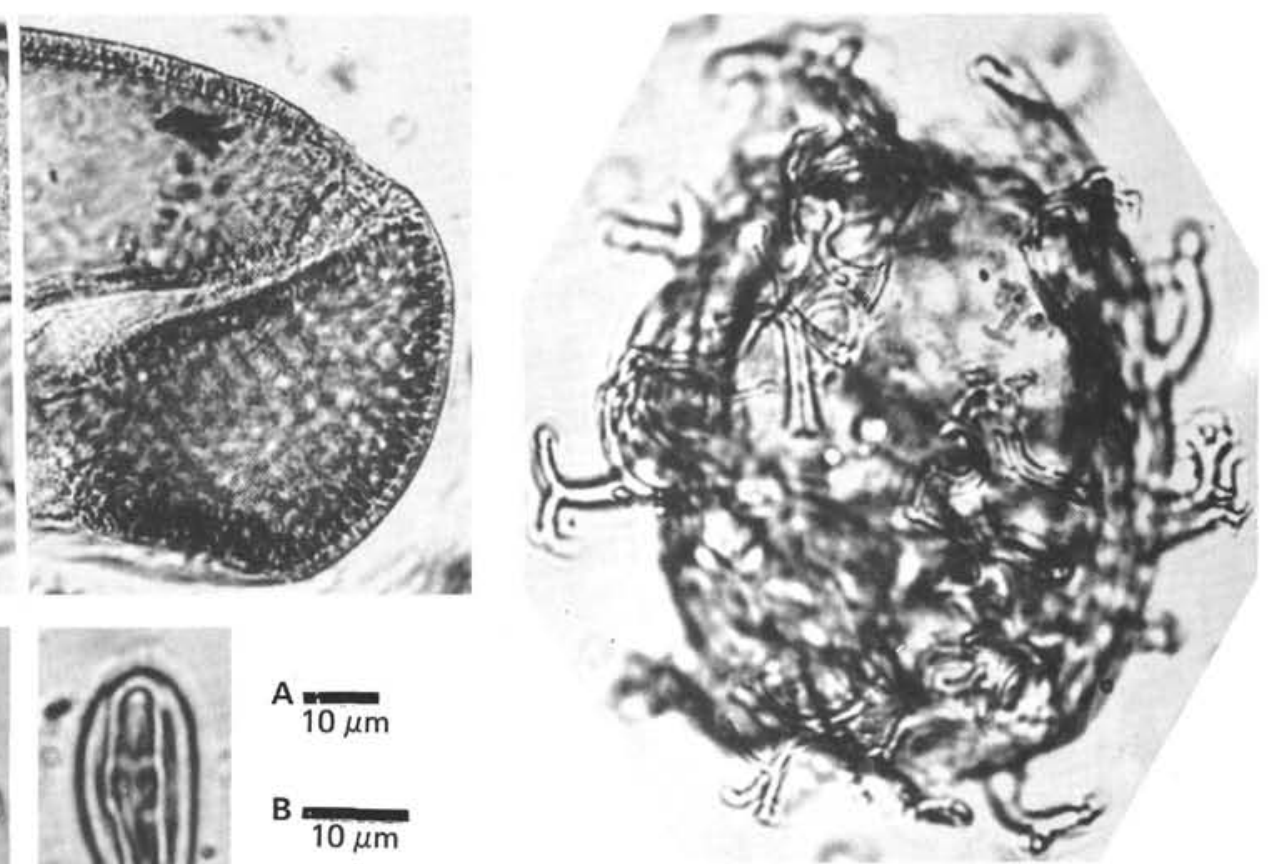

5

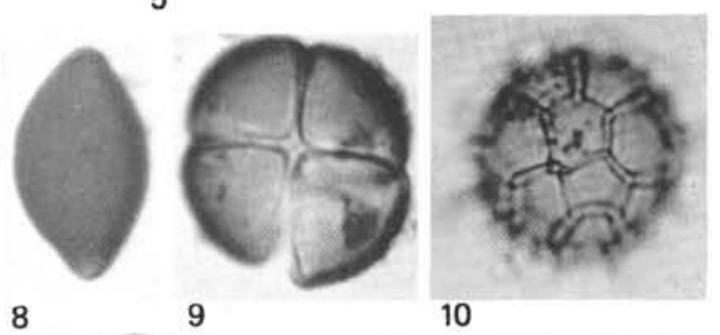

8

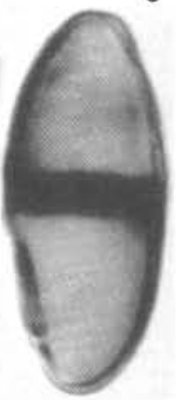

12

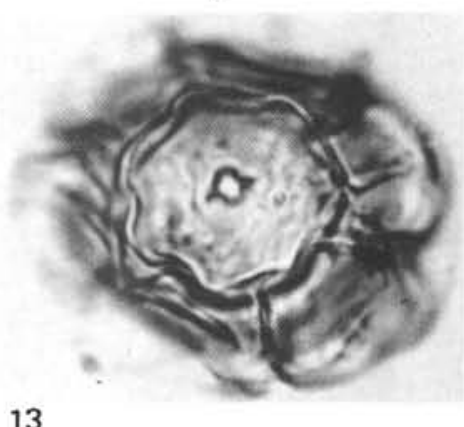

11

Figure 5 Figure 6 Figure 7 Figure 8 Figure 9

Figure 10

Figure 11

Figure 12

Figure 13

The same grain at one extremity. Liliiflorae.

\section{Liliiflorae.}

The same grain at a different focus. Pistacia.

Myrica.

Myrica.

Corylus.

Alnus. 
PLATE 5
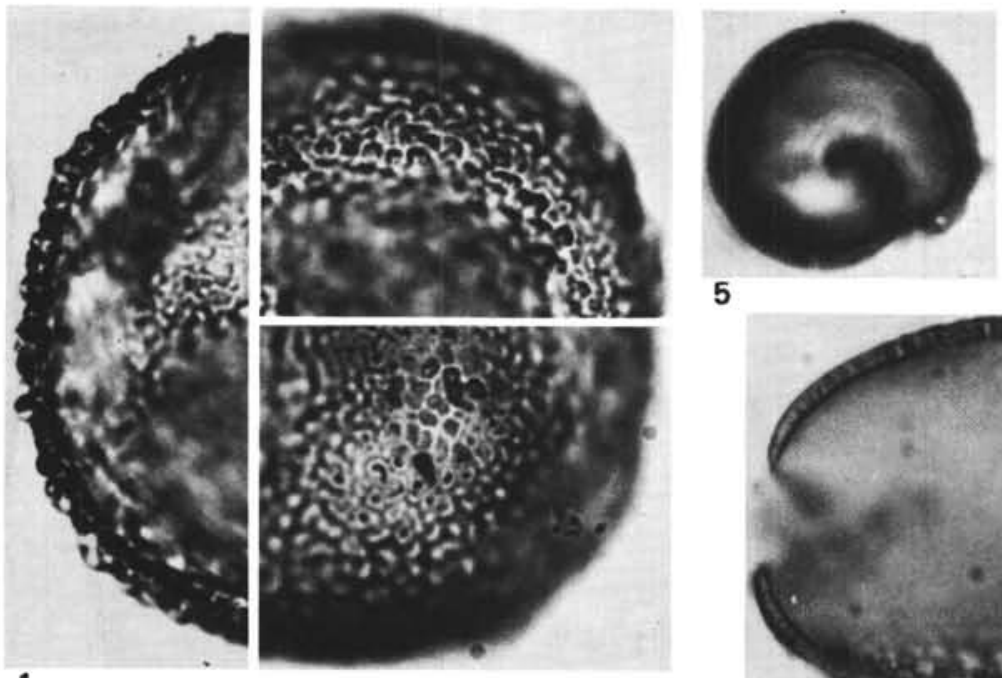

5
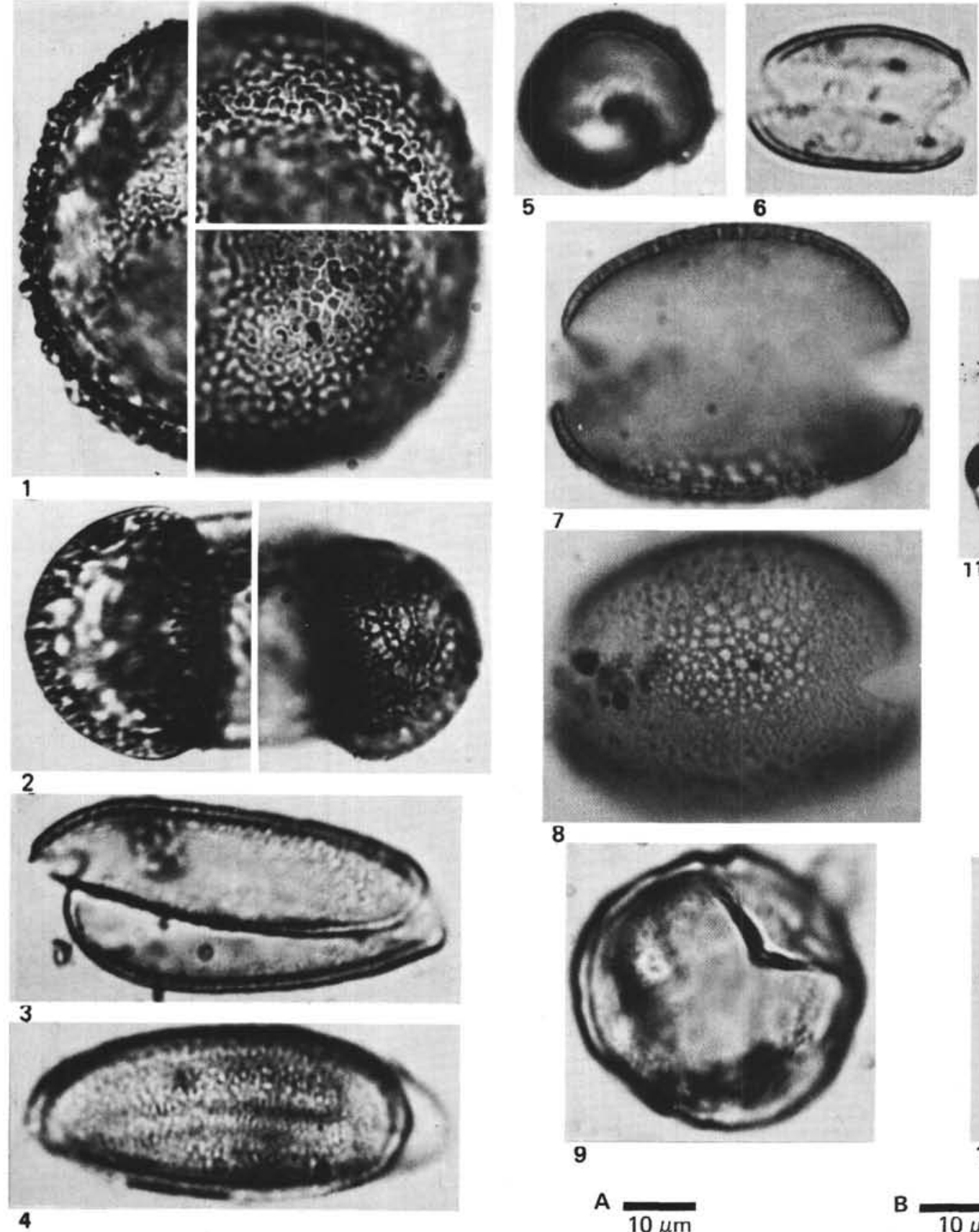

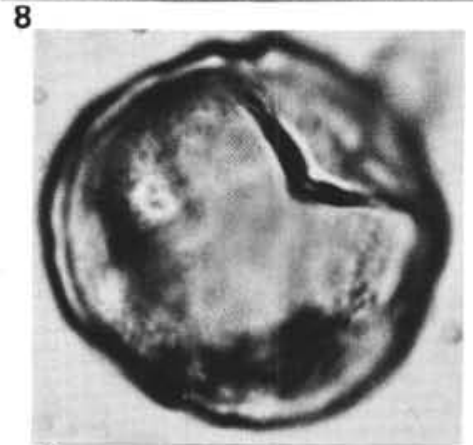

9

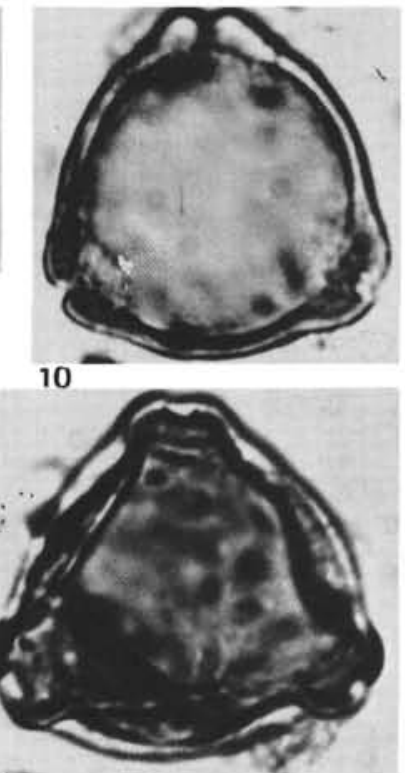

11

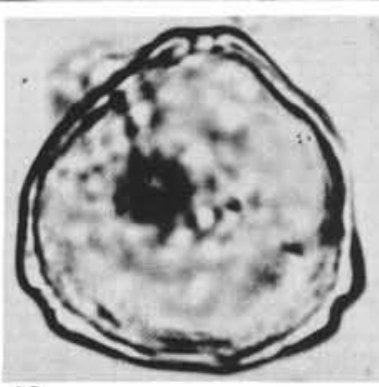

12

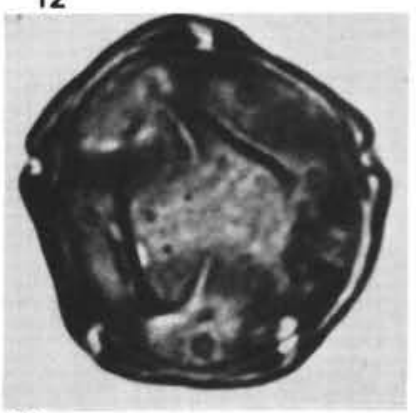

13

$10 \mu \mathrm{m}$
All grains are from Sample 374-5-2, 48-51 cm, except 4 and 5 which are from Sample 374-9-2, 0-7 cm.

Figure 1 Ephedra (distachya-type).

Figure 2 Ephedra (fragilis-type).

Figure 3 Graminaceae.

Figure 4 Compositae (Liguliflorae-type).

Figure 5 Cyperaceae.

Figure 6 Chenopodiaceae.
Figure 7

Figure 8

Figure 9

Figure 10

Figure 11

Figure 12

Figure 13
The same grain using a different focus. Chenopodiaceae.

The same grain using a different focus. Thalictrum.

Chenopodiaceae.

Campanula.

Artemisia. 


\section{PLATE 6}
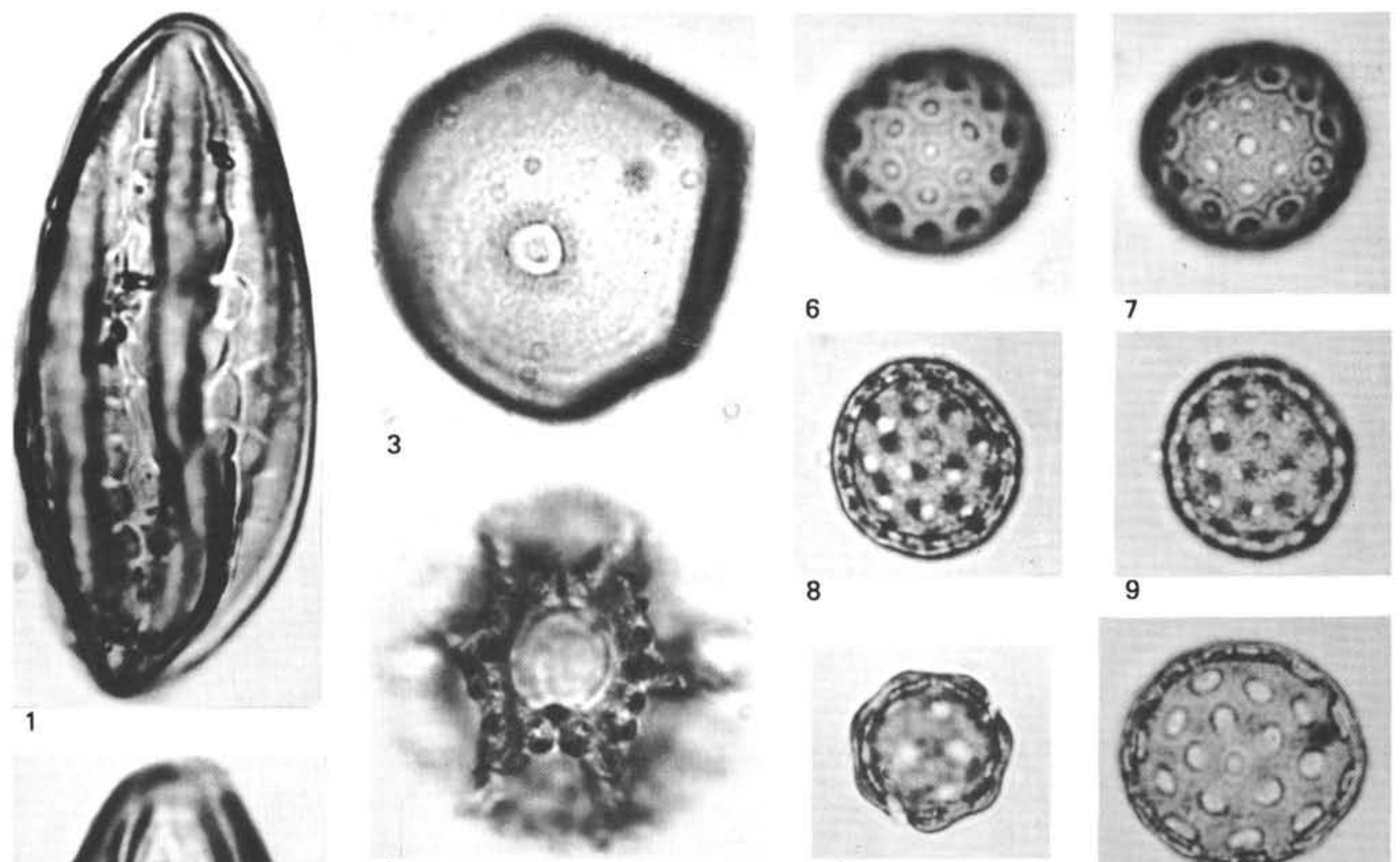

6

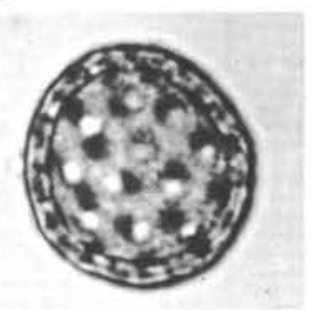

8
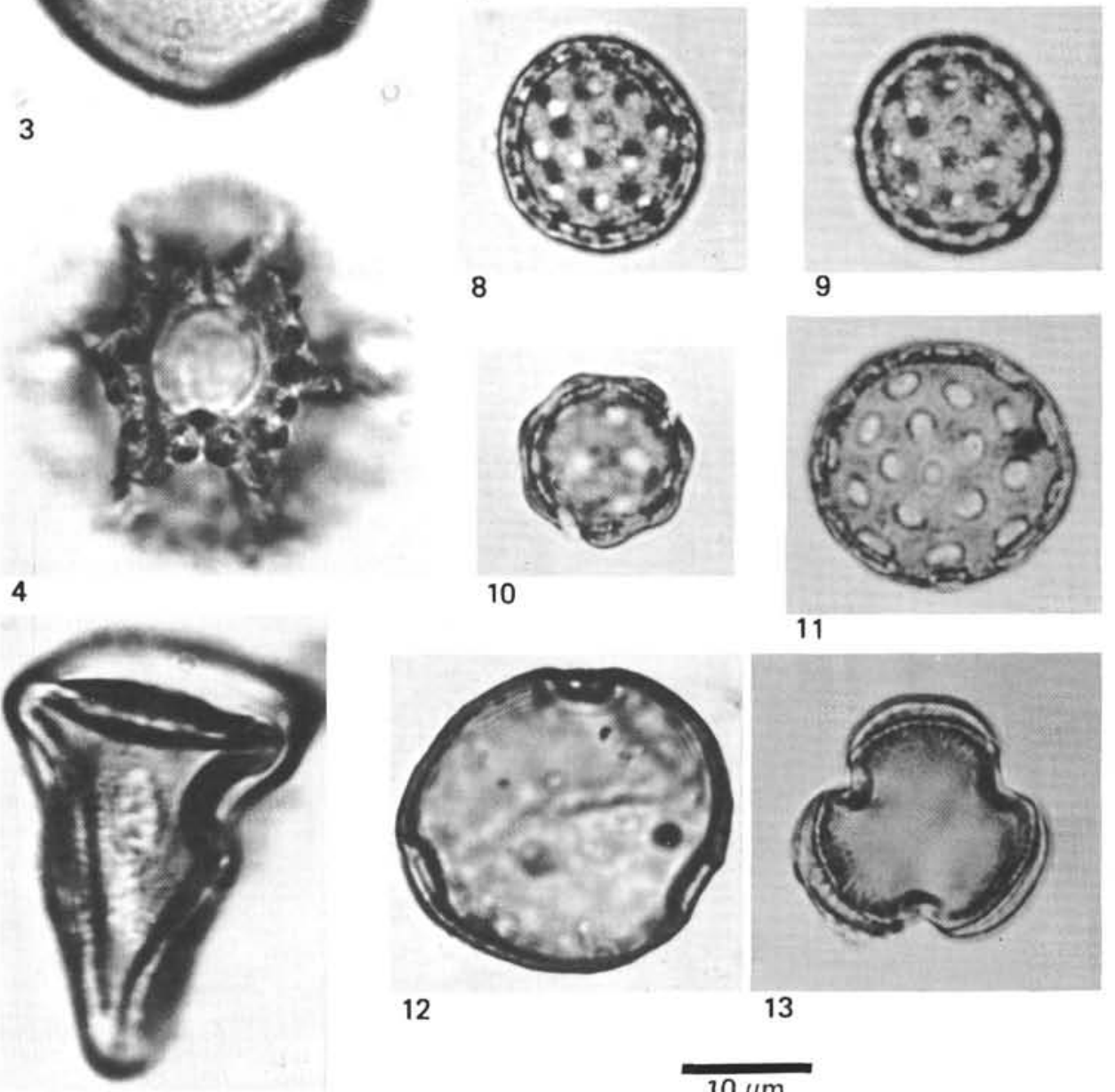

5

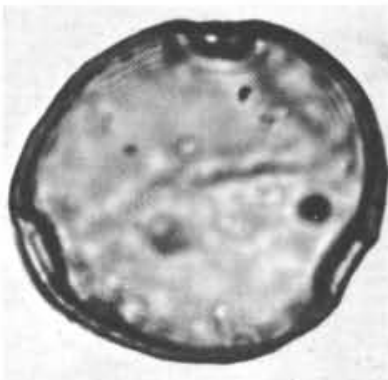

12

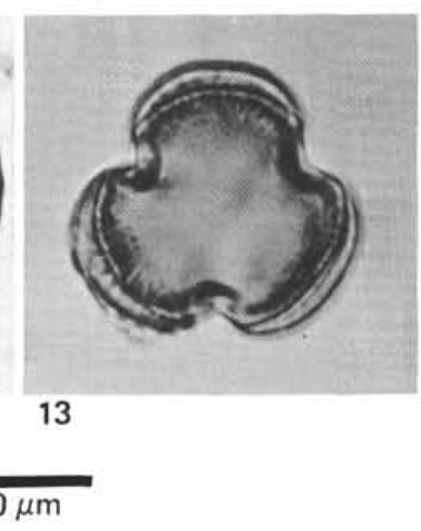

Figure 1-Scale A. Figures 2 and 5-Scale B. Figures 3, 4, $6,7,8,9,10,11,12$, and 13-Scale C. All Figures are from Sample 374-9-2, 0-7 cm except Figure 2.

Figure 1 Picea.

Figure 2 Pterocarya.

Figure 3

Figure 4 Figure 5

Figures 6-12

Figure 13
Castanea.

Unidentified pollen. Hystrichosphaeridia.

Fungal spores.

Fungal spores? 


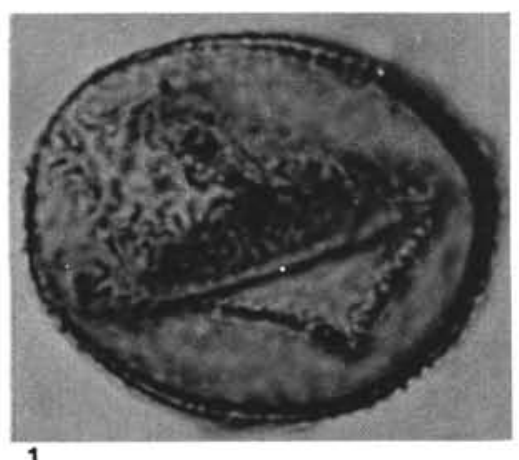

1
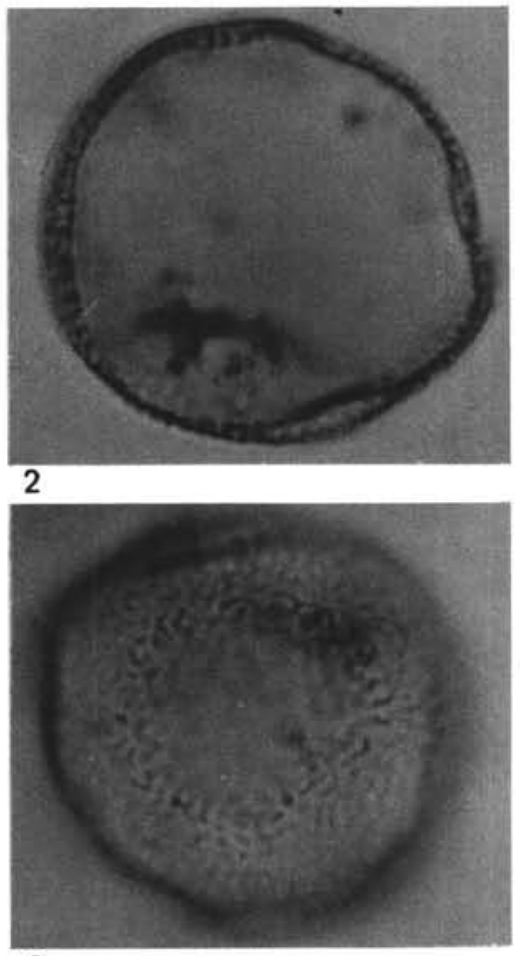

3

$$
10 \mu \mathrm{m}
$$
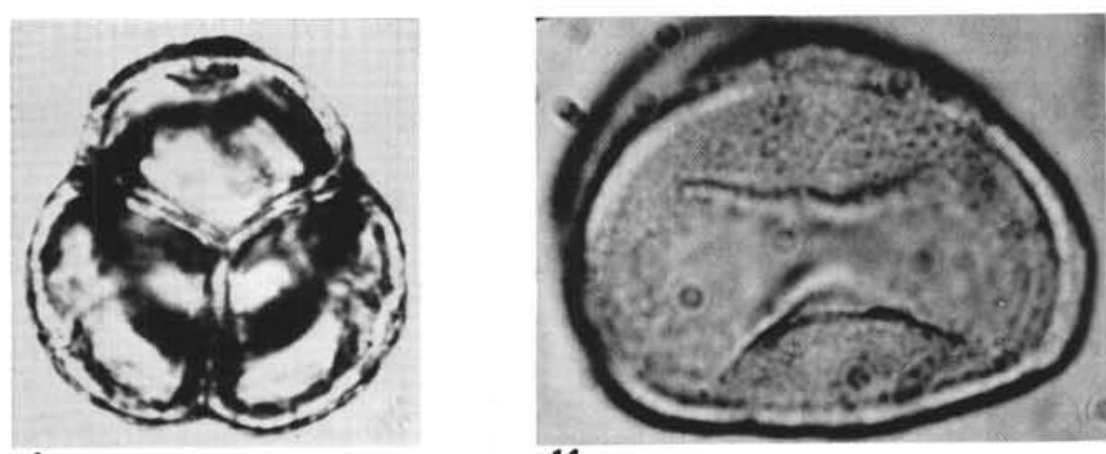

11

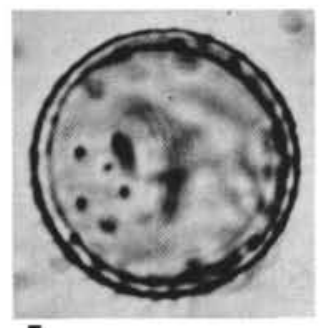

5
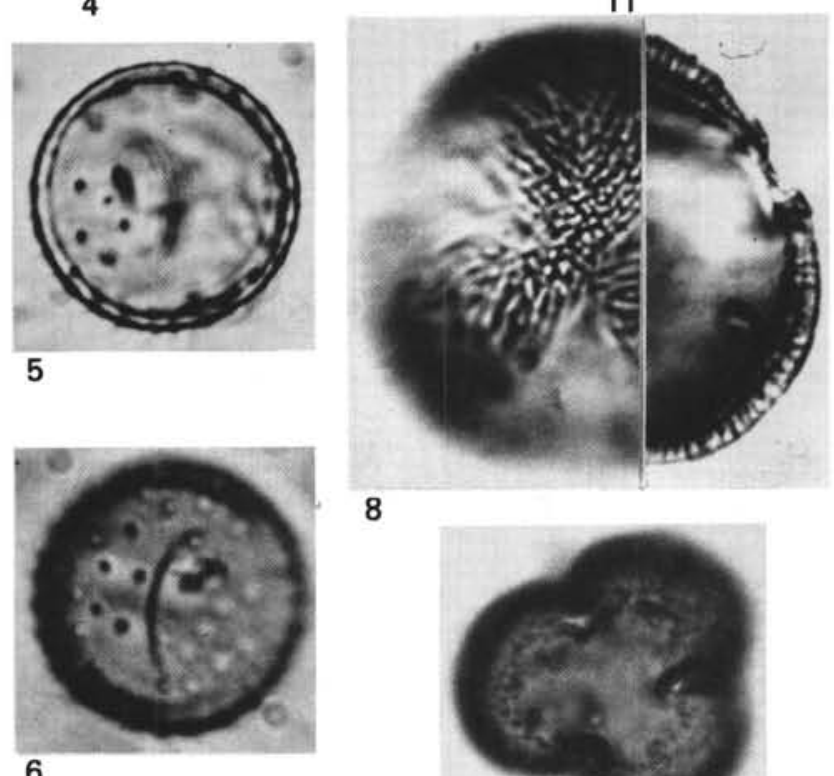

8

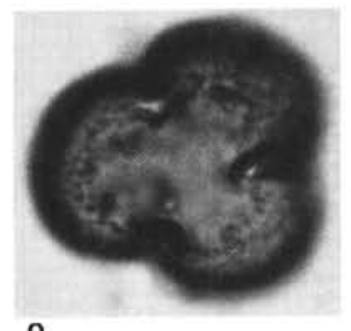

9
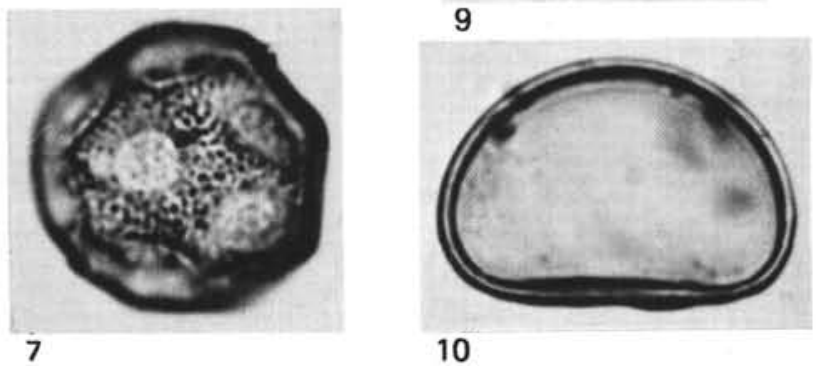

10
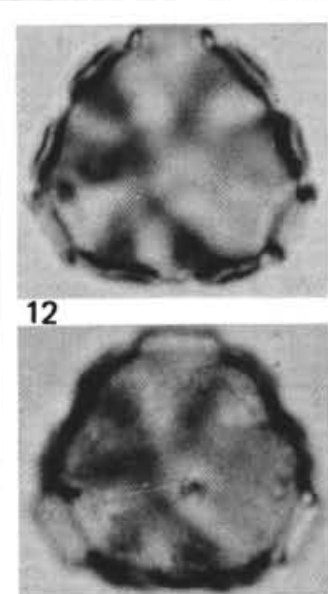

13

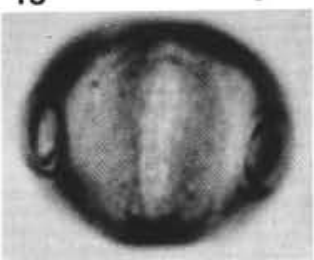

14

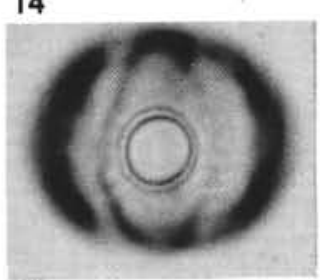

15
Location: grains 1, 2, 3, 5, 6, 7, and 11 from Sample 374-9-2, 0-7 cm; grain 4 from Sample 374-4, CC, level L; grain 8 from Sample 374-4, CC, level M; grains 9, 10, $12,13,14$, and 15 from Sample 374-5-2, 48-51 cm.

\section{Figure 1 Potamogeton.}

Figures 2, 3 Potamogeton at different foci.

Figure 4 Ericales.

Figures 5, 6 Lemna at different foci.

Figure 7 Alisma.
Figure 8

Figure 9

Figure 10

Figure 11

Figures 12, 13 Lythrum in polar view at two different foci.

Figures 14, 15 The same grain, two different equatorial views. 